\title{
Characters and Narrators as Interpreters of Fidelity Tests in Medieval Arthurian Fiction
}

\author{
Bart Besamusca
}

Published online: 9 January 2010

(C) The Author(s) 2010. This article is published with open access at Springerlink.com

\begin{abstract}
This article discusses a number of fidelity-testing tales and episodes, focusing on the function of characters and narrators who provide interpretations of the outcome of the tests. The testing of a series of characters takes place during a social gathering, involves a testing device, most often a mantle or a drinking horn, and discloses infidelity or other shortcomings. In most tales, ethical interpreters confront the spectators with social criticism and moral lessons, either seriously, as in Ulrich's Lanzelet and Albrecht's Jüngerer Titurel, or humorously, as in the Manteau mal taillé. In Heinrich von dem Türlin's Diu Crône, however, the interpreters are innocuous. Kei the seneschal and the narrator participate in an intratextual as well as literary game. Their comments are meant to amuse other characters, and to challenge the literary expertise of the listeners to Heinrich's romance.
\end{abstract}

Keywords Medieval literature - Arthurian fiction · Fidelity-testing motif · Diu Crône

\section{Introduction}

One of the English texts which have come down to us in the famous Percy Folio, the mid-seventeenth century codex acquired by the antiquarian bishop Thomas Percy (1729-1811) and now in the British Library (Additional MS 27879), is the ballad The Boy and the Mantle. In just under two hundred lines, this late-fifteenth-century narrative manages to relate a triple testing of the Arthurian community. A young boy brings a mantle to court, which "shall neuer become that wiffe / that hath once

B. Besamusca ( $\square)$

Department of Dutch Studies, Universiteit Utrecht, Trans 10, 3512 JK Utrecht, The Netherlands e-mail: A.A.M.Besamusca@uu.nl 
done amisse" (11. 29-30). ${ }^{1}$ Whereas Queen Guinevere tries on the mantle unsuccessfully-it looks as if it has been slashed with scissors and changes colours continuously (11. 39-48) - the wife of Craddocke passes the test, her only sin consisting of having kissed her husband once before they were married (11. 111-122). The second test involves a wild boar's head, which cannot be carved by "a cuc[k]olds kniffe" (l. 163). Craddocke is the only man to meet the challenge: "He britled the bores head/wonderous weele,/that euery knight in the kings court/had a morsell" (11. 175-178). Finally, the same knight is the only one who, due to his wife's faithfulness, is able to drink from a magic horn without spilling its contents.

Although a triple testing seems a little bit over the top, the author of The Boy and the Mantle is certainly no exception in his preference for this narrative element. A large corpus of texts testifies to the popularity of the testing motif in medieval Arthurian literature. From the second half of the twelfth century onwards, starting in the French area with Robert Biket's Lai du cor, the First Continuation de Perceval and the Manteau mal taillé, the test appears both in short tales and in episodes embedded in longer narratives. Like in The Boy and the Mantle, these tests are public events, characterized by a number of features. First of all, there is a testing device involved, most often a mantle or a drinking horn, occasionally a cup or a bridge and more seldom a boar's head, a glove or a crown. Secondly, a series of characters, be they exclusively female, exclusively male, or a mixed group, have to undergo the test. Thirdly, the event takes place during a social gathering. ${ }^{2}$

Traditionally, critics refer to this motif as the chastity or fidelity test. These names accurately characterize what is at stake in many texts, including The Boy and the Mantle, the Manteau mal taillé, the First Continuation de Perceval, the Tristan en prose, the Norse Möttuls saga, the German narratives Der Mantel and the Rappoltsteiner Parzival, the Italian Tavola Ritonda, the Icelandic Skikkjurimur ("Mantle Rhymes"), and Thomas Malory's Morte Darthur. ${ }^{3}$ It should be noted, however, that in a number of texts the nature of the transgression is more complex than simply infidelity. Three tales may suffice to illustrate this point. In his 1985 article, Jeff Rider has rightly remarked that already at the beginning of the tradition, in Biket's Lai du cor, the magic object, a horn made by a fairy, is said to expose not only a wife's unfaithfulness:

cest corn fist une fee

ranmponeuse, iree,

e le corn destina

que ja houme(e) n'i bev(e)ra,

tant soit sages ne fous,

s'il est cous ne gelous;

\footnotetext{
1 Furrow (1985, pp. 295-311).

${ }^{2}$ For an overview of the corpus, see in particular Kasper (1995). Cf. also Warnatsch (1883, pp. 5-84), Child (1956, pp. 257-271), Bennett (1975, pp. VII-XXIV) and Kalinke (1991).

${ }^{3}$ Cf. Bennett (1975, 11. 201-11), Roach (1949-1952, vol. 1, 11. 8559-8562 (T), vol. 2, 11. 12331-334 (E), vol. 3, 11. 3171-3174 (P)), Curtis (1985, par. 526, 20-21), Kalinke (1999, pp. 12-15), Warnatsch (1883, 1. 598), Schorbach (1888, 11. 7335-38), Polidori (1864-1865, p. 158), Kalinke (1999, pp. 292-293: second fit, stanzas 31-32), Vinaver and Field (1990, vol. 1, p. 429, 11. 31-35).
} 
ne ki nule femme (h)eit

qui (h)eit fol pensé feit

vers autre k'a lui. 4

This horn was made by a vengeful and wicked fairy, who took care that neither a man, whether wise or foolish, can drink from it if he is cuckolded or jealous, nor his wife when she has had a foolish thought on someone other than him.

In the German Lanzelet (ca. 1200), written by Ulrich von Zatzikhoven, a mermaid sends a mantle to Arthur's court which reveals improper behaviour concerning courtly conventions. Characters should comply with "die höfischen Regeln für das Zusammmenleben der Geschlechter". 5 The garment shows, for example, that a lady is sharp tongued, that another woman is foolishly obstinate, and that a man travelled about with his wife too much. ${ }^{6}$ In Albrecht's Jüngerer Titurel (ca. 1270-1275), the testing device is a bridge. Only men and women who are completely virtuous and not full of "spot und falscheit" (derision and treachery) may cross it."

Comparative research into the texts featuring the fidelity-testing motif is a rewarding enterprise. ${ }^{8}$ Critics have highlighted the many parallels and differences between the tales, focusing among other things on the testing devices, the identity of the characters who fail and of those who pass, and the varying reactions of both the victims of the testing objects and the spectators. Seen against the background of the whole tradition, for example, King Marc grossly overreacts when he threatens to execute the almost one hundred unfaithful ladies, including Isolde, in the Tristan en prose and in Malory's version of this episode in the Morte Darthur. ${ }^{9}$ In some tales, King Arthur's reaction is remarkable as well. Biket's Lai du cor presents him as a king who loses control completely, threatening his wife with a knife. ${ }^{10}$ In striking contrast to this situation, his reaction is curiously indifferent in the late-fifteenthcentury Sir Corneus, also known as The Cuckold's Dance. According to this tale, the king owns the horn and pokes fun at the cuckolded knights by having them seated at a separate table. When the queen's infidelity is eventually proven, Arthur declares himself their brother, ready to join the cuckolds' dance. He even thanks the man who took such good care of the queen in his absence. ${ }^{11}$

A feature of the fidelity-testing tales which deserves closer attention than has been given to it so far is the subject of this article. It concerns the comments made

\footnotetext{
4 Bennett (1975, 11. 229-237). See Rider (1985, p. 176).

5 Kasper (1995, p. 580).

${ }^{6}$ Kragl (2006, 11. 5744-6157).

7 Wolf (1964, stanza 2391, 1. 2).

8 Cf. Baumgartner (1975), Kasper (1995), Kelly (2000, pp. 63-90, 163-167), Koble (2005, pp. 103-144).

9 Cf. Curtius (1985, vol. 2, par. 531), Vinaver and Field (1990, vol. 1, p. 430, 11. 12-17). In the Italian parallel, the Tavola Ritonda, the king threatens to execute 673(!) exposed women, again including his wife, cf Polidori (1864-1865, p. 159).

10 Bennett (1975, 11. 297-300).

11 Furrow (1985, pp. 273-291, 11. 218-25).
} 
by characters and narrators on the often spectacular outcomes of the tests. ${ }^{12}$ In these passages, they provide interpretations of what is shown. They inform us, for example, why a mantle is shrinking in a certain way. By disclosing the nature of the victim's transgression, they give an indication of what has (allegedly) happened in the past. While commenting on fidelity tests is not a ubiquitous characteristic of the motif, there is a clear difference discernable between those texts where interpretations based on the results of the test are absent and the stories in which characters and narrators provide more detailed information on the failures. This essay will show that these commentaries contribute significantly to the meaning of the texts.

\section{Ethical Interpreters}

In Ulrich von Zatzikhoven's Lanzelet the character who introduces the testing device at court is also the one who interprets the events. "Diu maget, diu ez allez beschiet" (1. 5995), the maiden who explained everything, tells the court, for example, what it signifies when the mantle fits King Giferreiz's wife well, "wan ein michel loch gie dar în; / daz solt doch vermachet sîn / mit eim uosezzele breit" (except that it showed a large hole; that would still have to be covered with a broad patch). ${ }^{13}$ The shortcoming of the lady is that she hates her husband because of his small size (11. 6025-6027). The maiden reproaches her for this attitude, as the lady should know that "swi doch vil bezzer waere / ein maezlich man mit fuoge / danne grôzer manne gnuoge" (a small man of worth is much better than most of the big men; 11. 6028-6030). Due to her status as the messenger of the mermaid who sent the mantle to Arthur's court, the maiden speaks with authority. Consequently, the listeners to Ulrich's narrative will be inclined to accept her moral lessons. A good husband should indeed carefully look after his wife; it is indeed shameful when a woman accepts a man's gifts and yet leaves him unrewarded; etc. (11. 5995-6103). These interpretations greatly contribute to the narrative's "minnedidaktischen Grundcharakter". ${ }^{14}$

In Albrecht's Jüngerer Titurel, it is not a character who reveals the faults of the members of Arthur's court, but a "prief" (stanza 2392), an inscription, on a magic bridge. ${ }^{15}$ The bridge throws disloyal men off, and causes the horses of unchaste women to stumble. The inscription informs the spectators about each victim's shortcoming, albeit that in the case of a married woman the onlookers avoid reading the message, because her fault is a source of shame to her husband as well (stanzas 2392, 2400 and 2416). The knight Tidones, for example, is thrown off the bridge because of his envy (2394), and Fisodol Jofreite is unable to cross it because once upon a time he has kissed a woman against her will (2397). Erec ends up in the water as a result of his treating Enite as his "schilt kneht" (squire,

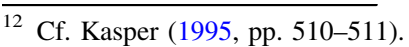

13 Kragl (2006, 11. 6021-6023).

14 Kasper (1995, pp. 100-102 (quote on 102), 569-580).

15 Wolf (1964).
} 
2399). ${ }^{16}$ Evidently, there is no reason whatsoever to doubt the trustworthiness and seriousness of the inscription. The status of this interpreter is comparable with the authoritative voice of the maiden in Lanzelet. Its denunciations of certain human weaknesses, like envy and pride, are unambiguous didactic lessons. ${ }^{17}$

The maiden in Lanzelet and the inscription in the Jüngerer Titurel are the exceptions in at least two respects. While they do not belong to Arthur's entourage and convey their lessons seriously, in the other tales we see Arthurian courtiers interpret the outcomes of a fidelity test and do so in a (supposedly) humoristic way. The best-known example of this narrative feature is the Manteau mal taille ${ }^{18}$ The mantle detects "les fausses dames" (the unfaithful ladies) and every damsel "qui vers son bon ami / avra mespris" (who has misbehaved towards her loyal lover). ${ }^{19}$ Following the example set by the abusive seneschal Keu, the knights interpret the mantle's ill fit as an indication of the exact nature of each victim's sexual transgression. Their bawdy comments are extremely explicit. According to Keu, for example, Ydier's lady "se fet cengler par derriere" (lets herself be mounted from behind, 1. 654).

In contrast to the words of the two interpreters in Lanzelet and the Jüngerer Titurel, there is every reason to doubt the reliability of the comments expressed by Keu and his fellow-knights. It is, after all, not only unlikely that they really know how each of the tested women prefers to make love, the mantle's form can also be easily interpreted in other ways than in correspondence to sexual preferences. Indeed, it does not matter whether the knights speak the truth. Their interpretations serve other goals. Obviously, they are intended as a source of humour, because Keu calls them "nos gas" (1. 686), our jokes. However, it is telling that none of the comments causes the listening characters to laugh. It seems certain that the French author aimed at a humoristic effect, but I would argue that he pursued a more serious goal as well.

At the end of Mötuls saga, the Norse adaptation of the Manteau mal taillé, the narrator states: "Nú ræoi engi annat til Peira en gott, Pvíat betr sómir at leyna en upp at segja, Pó at hann viti sanna sakir" ("Now let no one say anything but good about women, because it is more fitting to conceal than to reveal something, even though one may know the true state of affairs"). ${ }^{20}$ This conclusion provides the key

\footnotetext{
16 In the next stanza, the narrator makes this reference to Harmann's Erec explicit by addressing his famous predecessor, "Herr und vriunt von Owe, her Hartman der wise".

17 Cf. also Kasper (1995 pp. 613-25). Ulrich Füetrer's Buch der Abenteuer, composed in the last quarter of the fifteenth century, features a magic bridge episode which is an adaptation of the Jüngerer Titurel. As in Albrecht, there is an inscription functioning as interpreter: "An der pruck stúnd geschriben/ains yeden manns unfúeg" (Thoelen and Bastert 1997, stanza 1143). And there are, of course, more parallels. Curiously, Füetrer deviates from the fidelity-testing tradition by describing that Guinevere crossed the bridge smoothly, "frölich [...] sunnder peytten" (merrily, without halting, stanza 1152); Albrecht does not mention the queen. Even more interesting is the fact that the narrator links the fictional situation to Ulrich's fifteenth-century reality. He expresses the wish that "Albrecht in Bayrenlanndt", that is Füetrer's supposed patron Albrecht IV, Duke of Upper Bavaria, had a magic bridge at his disposal, which would enable him to know whether people are loyal or disloyal (stanzas 1150-1151).

18 Also entitled the Lai du Cort Mantel, Lai du Mantel and Le Conte du Mantel.

19 Bennett (1975, 11. 202, 208-209).

${ }^{20}$ Kalinke (1999, pp. 28-29).
} 
to a proper understanding of the bawdy comments in both this text and its French source. Specifying the exact nature of the transgression is above all deeply humiliating to the victims. The comments confirm that the tested women are unfaithful and, even more embarrassing, they suggest that the victims have enjoyed types of sexual intercourse which were condemned by the church, which only allowed the husband-on-top position. ${ }^{21}$ Both the women and their husbands are verbally dishonoured. By means of the interpreters, the Manteau mal taillé thus highlights the gap between the propagated ideal of fidelity and everyday reality.

Centuries later, the German author of Das Vasnachtspil mit der Kron (The Shrovetide Play with the Crown) applied the same strategy. The testing device in this fifteenth-century play is said to suit those kings "Die ir eer nicht haben verlorn" (who have not lost their honour). ${ }^{22}$ One of the failing royal husbands is the King of the Orient: when he tries on the crown, two goat's horns appear on it (p. 657, 11. 1015). ${ }^{23}$ His herald serves as interpreter, bluntly revealing that the king secretly makes love to a "müllnerin", a miller's wife, and that no peasant's daughter is safe from him (p. 657, 11. 16-22). Like the Manteau mal taille, the German text elucidates the gap between appearance and actual behaviour, which is in this case accentuated by the king's sexual excesses. Every girl of low birth can fall victim to his lust, which is so unbridled that he even commits adultery with a wife whose husband is famous for his sexual appetite in medieval literature. ${ }^{24}$ Both the king and the miller are presented as lechers. The king's humiliation is further emphasized by his foolish excuse: he argues that he slept with another woman in order to spare his wife, so that she would stay beautiful (p. 658, 11. 9-22). In reaction, the herald points out the ridiculous nature of the king's claim (11. 24-33).

\section{Innocuous Interpreters}

An exceptional type of interpreter has been created by the German author Heinrich von dem Türlin. His romance Diu Crône (ca. 1235) features two lengthy episodes which relate a test, the first one involving a "chopf", a tankard, the second one a "hentschüch", a glove. ${ }^{25}$ In spite of Heinrich's claim that he is translating a French tale written by Chrétien de Troyes (11. 23045-23047, 23982), it is very likely that the glove episode is his own invention. ${ }^{26}$ Evidently taken with this narrative element, Heinrich even refers to a third test, featuring a mantle. In the glove episode, the narrator states that he has already told the stories of the tankard and the mantle

\footnotetext{
${ }^{21}$ Cf., for example, Brundage (1996, pp. 40-43).

22 Von Keller (1965, nr. 80, pp. 654-663; quote p. 655, 1. 30).

23 According to Martin Walsh, "an actual booby-trap crown with springs for sprouting horns or expanding its circumference should not be ruled out" (1989, p. 317).

24 On the reputation of millers, see for example Van der Poel et al. (2004, nrs. 15, 21, 62, 178).

25 Cf. Knapp and Niesner (2000, 11. 918-2631) and Ebenbauer and Kragl (2005, 11. 22990-24699). The cup is described as a "chopf vnd ein lit" (1. 1073), tankard and lid, endowed with "stein vnd [...] feitivre" (1. 1114), jewels and ornaments.

26 Cf. Jillings (1980, pp. 19 and 23), Kasper (1995, p. 172), Kelly (2000, p. 84).
} 
(1. 23505), and that the mantle fitted Guinevere well (1. 23656). However, Diu Crône does not include this third test. It could be that Heinrich was thinking of a narrative attributed to him, that is Der Mantel, an adaptation of the Manteau mal taille $e^{-27}$

Heinrich's two testing episodes share a number of striking characteristics. ${ }^{28}$ For example, in contrast to the great majority of the fidelity-testing tales, in Diu Crône both men and women submit to the tankard and the glove tests. ${ }^{29}$ The tankard spills wine over men who are mean spirited or deceive their beloved, and over deceitful women (11. 1136-1146). When someone puts on the glove, it makes the right side of a character's body invisible except for the part with which the individual has sinned (11. 23095-23099), disclosing various shortcomings, like false speech and thoughts of maidens, false thoughts and deeds of women, and coarseness and cowardice of knights (11. 23124-23135).

An astonishing joint feature of the two tests concerns the positive portrayal of the royal couple. In contrast to many other testing tales, they pass both tests in Diu Crône, albeit that in the case of the queen a minor shortcoming is revealed twice. While she spoils such a little bit of wine "daz man ez chaum gesach" (that it was hardly noticeable; 1. 1281), King Arthur drinks from the tankard without spilling a drop, to the amazement of the court (11. 1897-1905). The glove makes the queen's lips visible, because in the past she was forced to kiss her abductor Gasowein, as the seneschal explains (11. 23609-23655). At the same time, the commentator Kei states that she is "aller frauwen trùwen zil" (a model of faithfulness to all women; 11. 23661). Both Gawein (11. 24419-24425) and the king (11. 24342-24348) pass the glove test. His nephew calls Arthur "min herr sonder missedat" (my faultless lord; 1. 24353). The fact that the quintessential representatives of the court are completely (the king) or nearly (the queen) faultless strongly suggests that Heinrich was, in contrast to many other authors of fidelity-testing narratives, not interested in presenting moral and social criticism. ${ }^{30}$

This view is corroborated by the interpretations provided in both tests by Kei and the narrator. ${ }^{31}$ The ethical aspect of their comments is doubtful. In the case of the seneschal, it should be noted that a large number of his extensive interpretations are too cryptic to make sense. ${ }^{32}$ In addition, the reactions of the characters confirm that we are not supposed to take Kei's interpretations and comments seriously. It is a recurring observation by the narrator that they laugh when Kei makes fun of the

\footnotetext{
27 Cf. Warnatsch (1883), Kasper (1995, pp. 606-612). However, see Schröder (2004, col. 965), who suggests that Der Mantel was composed in the fourth decade of the thirteenth century.

${ }^{28}$ Cf. Cormeau (1977, pp. 166-208), Jillings (1980, pp. 19-35), Martin (1984, pp. 110-114, 121-123), Meyer 1994, pp. 74-78), Kasper (1995, pp. 586-605), Bleumer (1997, pp. 255-263), Gutwald (2000, pp. 123-204).

29 Other examples include Albrecht's Jüngerer Titurel and Füetrer's Buch der Abenteuer (both men and women cross the bridge), and the First Continuation de Perceval (the horn Beneoiz tests the fidelity of both women and men, but only men try to drink from it).

30 Cf. also Jillings (1980, p. 12), Bleumer (1997, p. 259) and Gutwald (2000, pp. 157-162).

31 For the portrayal of Kei in Diu Crône, see in particular Baisch (2003).

32 Cf. Martin (1984, p. 111) and Gutwald (2000, p. 150).
} 
failures. ${ }^{33}$ Furthermore, at the end of the glove test the narrator explicitly doubts the seriousness of Kei's remarks. Observing that the seneschal ridicules everybody, including friends, kinsmen and himself, the narrator concludes: "warvmb solt es denn mich / besweren, was er sin getreib" (why, then, should I be troubled by anything he said; 11. 24669-24670)? Kei is a harmless interpreter.

Thomas Gutwald has convincingly argued that the two testing episodes in Diu Crône are particularly characterized by their playful nature. ${ }^{34}$ This explains why both the seneschal and the narrator do not convey moral messages. They participate in a game. A clear example of this feature are the cases in which Kei explains the outcome of the test by referring to something that happened to the victim in the past. Some of these remarks refer back to events related earlier in Diu Crône, like Kei's interpretation of Ygerne's shortcoming, indicated by her visible eye and ear (1. 23704). The seneschal recalls that Arthur's mother was in love with the magician Gansgüter, who won her over by playing his fiddle (11. 23706-23712; compare 11. 13179-13185). ${ }^{35}$ Kei's comment serves no other goal than to amuse both the seneschal's audience and the listeners to Heinrich's narrative.

Other interpretations concern events which are not included in Heinrich's tale. In these cases we are dealing with an intratextual game (a reference to the biographical past of a character, intended to amuse the spectators, or challenge their memory) and a literary game (a reference to another narrative, intended to amuse those listeners to Heinrich's romance who are acquainted with the literary tradition). ${ }^{36}$ For example, when Parcifal submits to the glove test, his right side does not vanish completely: a strip two fingers wide remains visible, from head to toe (11. 2460224606). As usual, Kei provides the interpretation, indicating as the knight's failures that in his childhood he left his mother dressed as a fool and that he took a ring from a lady and kissed her against her will (1l. 24617-24626). These shortcomings are related in Wolfram von Eschenbach's Parzival. ${ }^{37}$ In the case of other failing knights, like Lanzelet, Erec and Kalocreant, the seneschal also interprets the results of the glove test by disclosing their past. ${ }^{38}$ The listeners to Heinrich's narrative are playfully invited to remember the alluded episodes.

Heinrich's narrator participates in this game. Like the seneschal, he interprets in the tankard episode a number of knightly shortcomings by referring to their past. He declares, for example, that Lantzelet von Arlach, who was both a "riter vnd pfaffe" (1. 2076), a knight and a cleric, can not get a drink because he has ridden in a cart

\footnotetext{
33 Cf. 1l. 1319 (variant P), 1391, 1428, 1819, 1907, 23469-23470, 23720-23721, 24024, 24198. Cf. also Martin (1984, p. 113), Kasper (1995, p. 144) and Gutwald (2000, pp. 169-173).

34 Gutwald (2000, pp. 167-204).

35 Other examples: Guinevere allowed her abductor Gasowein to kiss her (11. 23647-23655; compare 11. 11610-11612), Amurfina would not let Gawein remain with Blandukors (11. 23759-23772; compare 11. 7796-817).

36 Cf. also Gutwald (2000, p. 173).

37 Weber (1981, Book III, 11. 126,19-131,21). The detail of the fool's clothing (called "tôren kleider" (1. 126,26) in Parzival) is absent in Chrétien's Perceval, cf. Busby (1993, 11. 496-733).

38 Lanzelet rode in a cart and, in particular, renounced the love of the goddess who raised him on an island in the sea (11. 24505-24522); Enite kept Erec's love by taking care of his horse (11. 24559-24572); Kalocreant was unhorsed by Laudin's husband, as he told himself (11. 24638-24651).
} 
while searching for Miliantz, who had carried of the queen (11. 2097-2126). In the case of Parcifal, the narrator gives the following interpretation of his failure (11. 2212-2224):

Ditz erwarb her Parcefal

An dem armen vischaer,

Den er in grozer swaer

Durch zuht vngevraget liez,

Als im div magt seit gehiez,

Daz in sein zuht so gar verriet,

Do er von dem boume schiet,

Da er si sitzent vant

Vnd des swertes kraft erkant,

Daz im gap sein oheim,

Do er wolt reiten heim.

Sweigen tuot vil dik schaden.

Sam wart er da mit geladen.

This was because of the poor fisherman whom the latter had abandoned to his pain since he did not think it proper to ask about it. Later, as he was leaving the tree in which the maiden was sitting, she said that his manners had betrayed him and then told him of the power of the sword his uncle had given him before Parzival set out for home. Silence often brings grief, and the nephew too became burdened with it. ${ }^{39}$

This type of interpretation hardly mocks the failing knights. ${ }^{40}$ Above all, the narrator is, of course, not addressing Arthur's courtiers. His remarks challenge the literary expertise of the listeners to Diu Crône.

It has been suggested that Heinrich intended to criticize the depiction of courtly life in other Arthurian narratives. ${ }^{41}$ However, this conclusion does not hit the nail on the head. Fun is the key word here. In tales like Lanzelet and the Jüngerer Titurel the interpretations serve a purely didactical purpose. They confront the audiences of Ulrich's and Albrecht's narratives with social criticism and moral lessons, and tell them how they should conduct themselves. In other tales, like the Manteau mal taillé, the interpreters convey an ethical message as well, but they do so by means of humour. In Diu Crône, however, there is no lesson. Both Kei and the narrator are innocuous interpreters, involving us in a literary game. Heinrich used the interpretations of the fidelity tests for the sole purpose of entertainment.

Acknowledgments I would like to thank Bernd Bastert, Frank Brandsma, Jessica Quinlan and Sacha Voogd for their comments on an earlier version of this article, that was presented at the XXIInd International Congress of the Arthurian Society in Rennes (July, 2008).

\footnotetext{
39 Thomas (1989, p. 26).

40 Other examples: King Brisaz did not help a maiden in distress (11. 1935-1940); in a forest Erec was warned of many dangers by Enite (11. 2163-2168).

41 Kelly (2000, p. 80).
} 
Open Access This article is distributed under the terms of the Creative Commons Attribution Noncommercial License which permits any noncommercial use, distribution, and reproduction in any medium, provided the original author(s) and source are credited.

\section{References}

Baisch, M. (2003). "Welt ir: er vervellet; / Wellent ir: er ist genesen!” Zur Figur Keies in Heinrichs von dem Türlin Diu Crône. In M. Baisch, et al. (Eds.), Aventiuren des Geschlechts. Modelle von Männlichkeit in der Literatur des 13. Jahrhunderts (pp. 149-173). Göttingen: V\&R unipress.

Baumgartner, E. (1975). A propos du Mantel mautaillié. Romania, 96, 315-332.

Bennett, Ph. (Ed.). (1975). Mantel et Cor. Deux lais du XIIe siècle. Exeter: University of Exeter.

Bleumer, H. (1997). Die Crône Heinrichs von dem Türlin. Form-Erfahrung und Konzeption eines späten Artusromans. Tübingen: Niemeyer.

Brundage, J. A. (1996). Sex and canon law. In V. L. Bullough \& J. A. Brundage (Eds.), Handbook of medieval sexuality (pp. 33-50). New York and London: Garland.

Busby, K. (Ed.). (1993). Chrétien de Troyes, Le Roman de Perceval ou Le Conte du Graal. Tübingen: Niemeyer.

Child, F. J. (Ed.). (1956). The English and Scottish popular ballads. Vol. 1. New York: Dover Publications. (reprint of New York 1884).

Cormeau, Ch. (1977). Wigalois und Diu Crone. Zwei Kapitel zur Gattungsgeschichte des nachklassischen Aventiureromans. Zürich and München: Artemis.

Curtis, R. L. (Ed.). (1985). Le roman de Tristan (Vol. 2). Cambridge: Brewer. reprint of Leyden 1976.

Ebenbauer, A., \& Kragl, F. (Eds.). (2005). Heinrich von dem Türlin, Die Krone (Verse 12282-30042). Nach der Handschrift Cod. Pal. germ. 374 der Universitätsbibliothek Heidelberg. Tübingen: Niemeyer.

Furrow, M. M. (Ed.). (1985). Ten fifteenth-century comic poems. New York \& London: Garland.

Gutwald, T. (2000). Schwank und Artushof. Komik unter den Bedingungen höfischer Interaktion in der Crône des Heinrich von dem Türlin. Frankfurt am Main etc.: Peter Lang.

Jillings, L. (1980). Diu Crone of Heinrich von dem Türlin: The attempted emancipation of secular narrative. Göppingen: Kümmerle.

Kalinke, M. E. (1991). Chastity tests. In N. J. Lacy, et al. (Eds.), The New Arthurian encyclopaedia (pp. 81-83). New York \& London: Garland.

Kalinke, M. E. (Ed.). (1999). Norse romance II: The knights of the Round Table. Cambridge: Brewer.

Kasper, Ch. (1995). Von miesen Rittern und sündhaften Frauen und solchen, die besser waren: Tugendund Keuschheitsproben in der mittelalterlichen Literatur vornehmlich des deutschen Sprachraums. Göppingen: Kümmerle.

Kelly, K. C. (2000). Performing virginity and testing chastity in the Middle Ages. London \& New York: Routledge.

Knapp, F. P., \& Niesner, M. (Eds.). (2000). Heinrich von dem Türlin, Die Krone (Verse 1-12281). Nach der Handschrift 2779 der Österreichischen Nationalbibliothek. Tübingen: Niemeyer.

Koble, N. (Ed.). (2005). Le Lai du cor et Le Manteau mal taillé. Préface d'Emmanuèle Baumgartner. Paris: Éditions Rue d'Ulm.

Kragl, F. (Ed.). (2006). Ulrich von Zatzikhoven, Lanzelet. Vols. 2. Berlin and New York: De Gruyter.

Martin, A. G. (1984). Shame and disgrace at King Arthur's court: A study in the meaning of ignominy in German Arthurian literature to 1300. Göppingen: Kümmerle.

Meyer, M. (1994). Die Verfügbarkeit der Fiktion. Interpretationen und poetologische Untersuchungen zum Artusroman und zur aventiurehaften Dietrichepik des 13. Jahrhunderts. Heidelberg: Winter.

Polidori, F.L. (Ed.). (1864-1865). La tavola ritonda o l'istoria di Tristano. Vols. 2. Bologna: Romagnoli.

Rider, J. (1985). Courtly marriage in Robert Biket's Lai du Cor. Romania, 106, 173-197.

Roach, W. (Ed.). (1949-1952). The Continuations of the Old French Perceval of Chrétien de Troyes: The first continuation. Vols. 3. Philadelphia: University of Pennsylvania Press/American Philosophical Society.

Schorbach, K. (Ed.). (1888). Claus Wisse and Philipp Colin, Parzival (1331-1336), eine Ergänzung der Dichtung Wolframs von Eschenbach. Strassburg and London: Trübner. 
Schröder, W. (2004). Der Mantel. In B. Wachinger, et al. (Eds.), Die deutsche Literatur des Mittelalters. Verfasserlexikon, Vol. 11 (col. 962-965). Berlin \& New York: De Gruyter.

Thoelen, H., \& Bastert, B. (Eds.). (1997). Ulrich Füetrer, Das Buch der Abenteuer. Teil 1. Die Geschichte der Ritterschaft und des Grals. Göppingen: Kümmerle.

Thomas, J.W. (Trans.). (1989). Heinrich von dem Türlin, The Crown. A tale of Sir Gawein and King Arthur's court. Lincoln and London: University of Nebraska Press.

van der Poel, D. E., et al. (Eds.). (2004). Het Antwerps Liedboek. Vols. 2. Tielt: Lannoo.

Vinaver, E., \& Field, P. J. C. (Eds.). (1990). The works of Sir Thomas Malory (Vols. 3, 3rd edn.). Oxford: Clarendon Press.

von Keller, A. (Ed.). (1965). Fastnachspiele aus dem fünfzehnten Jahrhundert. Zweiter Teil. Darmstadt: Wissenschaftliche Buchgesellschaft. reprint of Stuttgart 1853.

Walsh, M. W. (1989). Arthur Соси: Comic abuse of the Round Table in Fifteenth-Century Fastnachspiele. Fifteenth-Century Studies, 15, 305-321.

Warnatsch, O. (Ed.). (1883). Der Mantel. Bruchstück eines Lanzeletromans des Heinrich von dem Türlin. Breslau: Koebner.

Weber, G. (Ed.). (1981). Wolfram von Eschenbach, Parzival. Text, Nacherzählung, Worterklärungen. Darmstadt: Wissenschaftliche Buchgesellschaft.

Wolf, W. (Ed.). (1964). Albrechts von Scharfenberg Jüngerer Titurel, Band II/1 (Strophe 1958-3236). Berlin: Akademie Verlag. 